\title{
CORRECTION
}

\section{Correction to: Effectiveness and potential mechanisms of intralipid in treating unexplained recurrent spontaneous abortion}

\author{
Lili Meng ${ }^{1}$ Jizong Lin ${ }^{2} \cdot$ Libin Chen $^{1} \cdot$ Zhenhua Wang $^{1} \cdot$ Meilan Liu ${ }^{1} \cdot$ Yukun Liu ${ }^{1} \cdot$ Xin Chen $^{1} \cdot$ Liqiong Zhu $^{1}$. \\ Hui Chen ${ }^{1} \cdot$ Jianping Zhang ${ }^{1}$
}

Published online: 23 October 2021

(c) Springer-Verlag GmbH Germany, part of Springer Nature 2021

\section{Correction to: Arch Gynecol Obstet (2016) 294:29-39 https://doi.org/10.1007/s00404-015-3922-8}

In the original article published, the table within "Figure 3" is duplicated with the table within "Figure 2", and the correct table is given below.

\begin{tabular}{lllll}
\hline & $\begin{array}{l}\text { Before treat- } \\
\text { ment }(\%)\end{array}$ & $\begin{array}{l}\text { After treat- } \\
\text { ment }(\%)\end{array}$ & $\begin{array}{l}\text { Pregnancy } \\
(\%)\end{array}$ & $P$-value \\
\hline $\begin{array}{l}\text { Intralipid } \\
\text { group }(n=\end{array}$ & $37.8 \pm 18.5$ & $26.6 \pm 10.8$ & $22.3 \pm 6.5$ & $P<0.001$ \\
$\quad$ 79) & & & & \\
$\begin{array}{l}\text { IVIG group } \\
(n=81)\end{array}$ & $37.1 \pm 18.3$ & $27.3 \pm 11.9$ & $22.1 \pm 8.5$ & $P<0.001$ \\
\begin{tabular}{l}
$P$ value \\
\hline
\end{tabular} & 0.488 & & & \\
\hline
\end{tabular}

The original article can be found online at https://doi.org/10.1007/ s00404-015-3922-8.

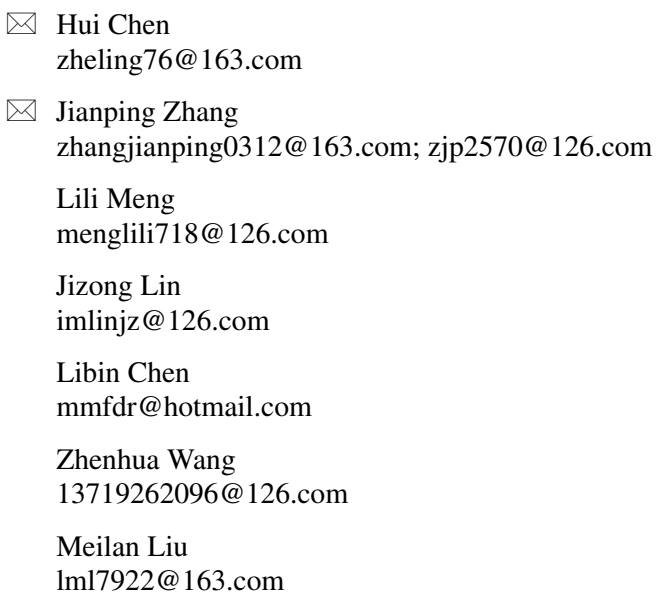

Publisher's Note Springer Nature remains neutral with regard to jurisdictional claims in published maps and institutional affiliations.

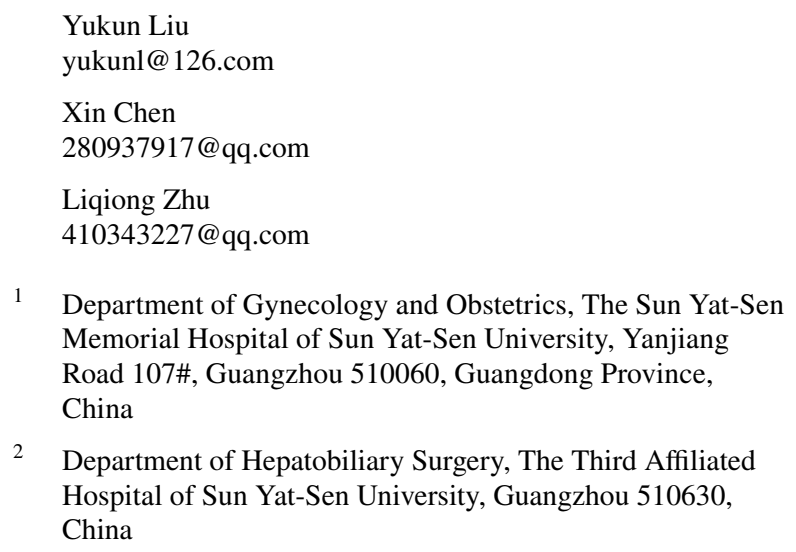
Memorial Hospital of Sun Yat-Sen University, Yanjiang Road 107\#, Guangzhou 510060, Guangdong Province, China

2 Department of Hepatobiliary Surgery, The Third Affiliated Hospital of Sun Yat-Sen University, Guangzhou 510630, China 